\title{
Breeding seabirds at Dassen Island, South Africa: chances of surviving great white pelican predation
}

\author{
Martin M. Mwema ${ }^{1,2, *}$, Marta de Ponte Machado ${ }^{1,2}$, Peter G. Ryan ${ }^{1}$ \\ ${ }^{1}$ Percy Fitzpatrick Institute, DST/NRF Centre of Excellence, University of Cape Town, Rondebosch 7701, South Africa \\ ${ }^{2}$ Animal Demography Unit, Department of Zoology, University of Cape Town, Rondebosch 7701, South Africa
}

Present address: Box 1019, 00100, GPO, Nairobi, Kenya

\begin{abstract}
Seabird predation by great white pelicans Pelecanus onocrotalus is an unusual phenomenon that has become increasingly frequent in the Western Cape, South Africa. We report the scale of pelican predation and its impact on the breeding success of 5 seabird species monitored at Dassen Island in 2006. Pelican predation was observed on chicks of kelp gulls Larus dominicanus, crowned cormorants Phalacrocorax coronatus and Cape cormorants Phalacrocorax capensis. No predation on eggs was seen. Breeding success for 4 of the 5 species studied was low, with the white-breasted cormorants Phalacrocorax lucidus having the highest breeding success ( 0.56 fledglings per nest). Cape and bank cormorants Phalacrocorax neglectus did not fledge any chicks, while crowned cormorants had a breeding success of 0.08 fledglings per nest. Kelp gulls had a hatching success of $46 \%$, but only a few chicks fledged, giving a breeding success of 0.06 fledglings per nest. Pelican predation poses a threat to at least 3 of the 5 seabirds studied, all of which are endemic to southern Africa. Three species are globally Endangered or Near Threatened, and pelican predation places additional pressure on these species. Management actions are needed to reduce or eliminate pelican predation.
\end{abstract}

KEY WORDS: Predation - Pelecanus onocrotalus - Breeding success - Larus dominicanus · Phalacrocorax spp.

Resale or republication not permitted without written consent of the publisher

\section{INTRODUCTION}

Pelicans (Aves: Pelecanidae) have large, pouched bills adapted to catch fish and other aquatic organisms. Although some species scavenge on land, they seldom eat other birds (Brown et al. 1982, del Hoyo et al. 1992) and, outside southern Africa, there have been few cases of pelicans eating birds. Brown pelicans Pelecanus occidentalis have been reported to eat eggs and chicks of cattle egrets Bubulcus ibis as well as chicks of great egrets Casmerodius albus and common murres Uria aalge in Mexico and California (Mora 1989). Australian pelicans $P$. conspicillatus are occasional predators of silver gulls Larus novaehollandiae and grey teal Anas gibberifrons (del Hoyo et al. 1992). In a case that generated considerable public interest, a feral great white pelican $P$. onocrotalus was filmed swallowing a live pigeon at a London park in October 2006 (BBC news 2006).
In southern Africa, unlike elsewhere, there have been numerous reported cases of pelicans eating seabirds. Great white pelicans were first recorded eating seabirds in the 19th century on Dyer Island, South Africa, where they ate the eggs and chicks of cormorants, gannets and other guano-producing birds, resulting in their persecution by guano collectors (Layard \& Sharpe 1884, Symons 1924, Brooke 1984). The first case of pelican predation on seabirds in Namibia was recorded in the 1970 s, when adult great white pelicans as well as older chicks were observed eating eggs and chicks of Cape cormorants Phalacrocorax capensis, at the Walvis Bay guano platform (Berry 1976). On Dassen Island, the earliest published record was in 1993 (Crawford et al. 1995), when a pelican was observed eating an adult Cape cormorant. Dassen Island also provided the first recorded observation of pelicans moving in groups to search for kelp gull Larus dominicanus chicks (Crawford et al. 1995). 
This observation was interesting because it suggested that the pelicans were adapting their cooperative foraging techniques, normally used in aquatic environments, to hunt seabird chicks on land.

In recent years, there has been an increase, not only in the number of pelican predation events, but also in the number of species targeted and the area covered (de Ponte Machado 2007). In addition to Cape cormorants and kelp gulls, pelicans also eat chicks of crowned cormorants Phalacrocorax coronatus, African penguins Spheniscus demersus, Hartlaub's gulls Larus hartlaubii and swift terns Sterna bergii (Wolfaardt 2000). The pelicans have recently expanded their area of predation from Dassen Island to the neighbouring Saldanha Bay islands (Hockey et al. 2005), where they are causing massive breeding failures (de Ponte Machado 2007). Predation in South Africa appears to be restricted to the Western Cape population breeding at Dassen Island. There have been no reports of pelican predation from the only other breeding pelican population in South Africa at Lake St. Lucia in KwaZulu-Natal (Hockey et al. 2005).

The recent increase in seabird predation in the Western Cape may be linked to an increase in the great white pelican population and a decrease in food availability as a result of the closure of pig farms that used to provide offal (de Ponte Machado 2007). The pelican population increased from between 20 and 30 pairs in the 1930s (Crawford \& Taylor 2000) to 650 pairs in 2001 (Hockey et al. 2005). This population increase was mainly due to: (1) protection from disturbance at their breeding area on Dassen Island, (2) building of farm dams, (3) introduction of the exotic carp Cyprinus carpio, and (4) availability of offal from pig and chicken farms (Crawford et al. 1995, Crawford \& Taylor 2000). The pelican breeding population doubled between the 1989/1990 and 1993/1994 breeding seasons (Crawford et al. 1995), when some pig farms started to make offal available.

In 2003, up to 1200 pelicans (approx. 60\% of the Western Cape population) were observed feeding on offal at a pig farm (de Ponte Machado \& Hofmeyr 2004), indicating a high reliance on offal as a food source. Offal also formed an important part of the diet fed to pelican chicks at Dassen Island from the 1990s (Crawford et al. 1995). Diminishing offal availability due to pig farm closures and changes in management at the one pig farm still operating may have, therefore, led the pelicans to seek alternative food sources (de Ponte Machado 2007). Similar prey switching has been demonstrated among great skuas Catharacta skua, which targeted seabirds after a reduction in the availability of fish discards (Votier et al. 2004).

We assessed the impact of great white pelican predation on seabirds breeding on Dassen Island by quantifying the number of chicks eaten and determining the breeding success of 5 potential prey seabird species.

\section{MATERIALS AND METHODS}

We studied the impact of pelican predation on 5 seabird species breeding on Dassen Island, 4 cormorants (Phalacrocoracidae) and one gull (Laridae). Three of the cormorants are endemic to southern Africa and are classified as Endangered or Near Threatened. The bank cormorant Phalacrocorax neglectus is Endangered (BirdLife International 2004), with a global population of some 2800 pairs, down from 7600 pairs in the late 1970s and early 1980s (BirdLife International 2009a). The crowned cormorant has a total population of some 3000 pairs (du Toit et al. 2003), but its population is stable, and it is listed as Near Threatened (BirdLife International 2004). The Cape cormorant's population is much larger, some 72000 pairs (BirdLife International 2009b), but it undergoes strong inter-annual fluctuations in breeding numbers and is also listed as Near Threatened (BirdLife International 2004). The white-breasted cormorant is not globally threatened and is widespread in sub-Saharan Africa, with a southern African coastal population of some 3100 pairs (du Toit et al. 2003). The Southern African kelp gull Larus dominicanus vetula (referred to in the following as 'kelp gull') is an endemic sub-species of the widespread southern hemisphere kelp gull (Jiguet 2002, Hockey et al. 2005). It is morphologically quite distinct from other kelp gull populations (Chu 1998) and has been treated as a distinct species by some observers (Sangster 1999). The local population of some 23000 breeding pairs has been increasing (du Toit et al. 2003) and it is not globally threatened.

Observations were conducted from 23 October to 15 December 2006 at Dassen Island, $\left(33^{\circ} 25^{\prime} \mathrm{S}\right.$, $\left.18^{\circ} 06^{\prime} \mathrm{E}\right)$ (Fig. 1), a 220 ha island (3.2 km long and $1.6 \mathrm{~km}$ wide) $55 \mathrm{~km} \mathrm{NW}$ of Cape Town (Wolfaardt 2000). The island is a Provincial Nature Reserve and is one of only 2 places in South Africa where great white pelicans breed (Barnes 1998). There are no wetlands on the island, so most pelicans commute to the mainland to forage. Pelican predation activities on the island were observed from the top of a lighthouse for 2 to $3 \mathrm{~h}$ a day for $7 \mathrm{wk}(\mathrm{n}=130 \mathrm{~h}$ ) using binoculars and a 30 to $60 \times$ telescope. The following information was recorded: the number and age classes of pelicans involved in each incident, the number of chicks eaten, and the time and duration of each attack.

Cormorant and kelp gull nests were monitored weekly for $7 \mathrm{wk}$. All cormorant nests were monitored apart from those at Ichaboe Point and the NE tip of the island near House Bay (Fig. 1). These latter areas were avoided to minimise disturbance of breeding African penguins. The numbers of nests monitored were: 107 Cape cormorant nests, 237 crowned cormorant nests, 


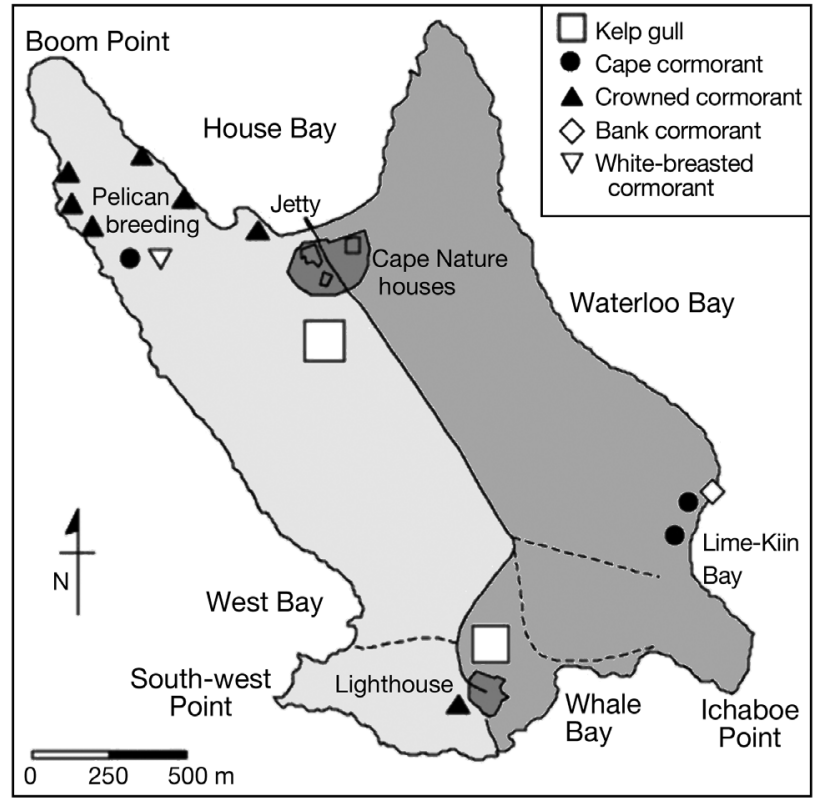

Fig. 1. Map of Dassen Island, South Africa, showing the colony locations of the 5 study species

23 white-breasted cormorant nests and 3 bank cormorant nests. Nests were monitored from approx. 50 to $70 \mathrm{~m}$ using a 30 to $60 \times$ telescope to avoid flushing cormorants from their nests, thus exposing eggs or small chicks to kelp gull predation. At each weekly visit, the number of eggs and chicks were counted during changeovers by the parents.

Of 144 kelp gull nests monitored, 70 were at the southern end near the lighthouse and 74 near the northern end, $700 \mathrm{~m}$ from the Cape Nature houses (Fig. 1). Each nest was marked using a coloured flag and its GPS location recorded. During monitoring, each nest was checked, and the number of eggs or chicks present, as well as the developmental stage of the chick, was recorded. When the chicks grew older and started to move around, telescope searches were used in addition to ground checks.

Crude breeding success was calculated as the number of fledged chicks per nest. Given incomplete coverage of the breeding season, Mayfield's at risk method (Mayfield 1961, 1975) was also used to determine nest success for white-breasted cormorants (i.e. number of cormorant nests likely to fledge one or more chicks). However, Mayfield's method was not used for the kelp gulls and other species of cormorants because the mortality rate was not constant, due to large predation events that caused catastrophic mortality (Johnson \& Shaffer 1990). The nesting period (incubation plus fledging period) of the white-breasted cormorant was assumed to be 79 d (Oliver \& Kuyper 1978).

\section{RESULTS}

Pelican predation was observed on chicks of kelp gulls, crowned cormorants and Cape cormorants (Table 1). All pelicans involved in attacks were adults. No egg predation was observed. Some kelp gull eggs may have been overlooked, because the birds were observed from a distance, but judging by the pelicans' behaviour most, if not all, prey were chicks. In one instance, the pelicans rushed into a crowned cormorant colony, flushed the incubating adults, and then ignored the exposed eggs. Predation on kelp gull eggs and small chicks by adult kelp gulls was observed.

Pelicans observed foraging on Dassen Island spent most of their time searching for and eating kelp gull chicks among rocks and dense Tetragonia bushes

Table 1. Great white pelican predation events observed at Dassen Island during the study period. Mean number of pelicans in parentheses

\begin{tabular}{|c|c|c|c|c|c|}
\hline Species & $\begin{array}{c}\text { Date } \\
\mathrm{dd} / \mathrm{mm} / \mathrm{yy}\end{array}$ & $\begin{array}{c}\text { Duration of predation } \\
\text { event (min) }\end{array}$ & $\begin{array}{c}\text { No. of } \\
\text { pelicans involved }\end{array}$ & $\begin{array}{c}\text { No. of } \\
\text { chicks eaten }\end{array}$ & $\begin{array}{c}\text { No. of } \\
\text { failed attempts }\end{array}$ \\
\hline Crowned cormorant & $20 / 11 / 06$ & 220 & 8 & 7 & 3 \\
\hline Cape cormorant & $18 / 11 / 06$ & 15 & 9 & 2 & 1 \\
\hline \multirow[t]{12}{*}{ Kelp gull } & 02/11/06 & 10 & 8 & 2 & 0 \\
\hline & $13 / 11 / 06$ & 77 & $9-39(22.2)$ & 16 & 7 \\
\hline & $14 / 11 / 06$ & 195 & $11-30(21)$ & 14 & 21 \\
\hline & $15 / 11 / 06$ & 285 & $10-44(22.4)$ & 50 & 26 \\
\hline & $16 / 11 / 06$ & 330 & $4-7(5.5)$ & 11 & 1 \\
\hline & 18/11/06 & 240 & $10-33(24.6)$ & 41 & 7 \\
\hline & $20 / 11 / 06$ & 220 & $13-55(28.9)$ & 18 & 6 \\
\hline & $21 / 11 / 06$ & 5 & 14 & 1 & 0 \\
\hline & $22 / 11 / 06$ & 6 & 24 & 1 & 0 \\
\hline & $27 / 11 / 06$ & 20 & 15 & 3 & 1 \\
\hline & $11 / 12 / 06$ & 10 & 3 & 1 & 0 \\
\hline & $13 / 12 / 06$ & 15 & 3 & 1 & 0 \\
\hline \multicolumn{2}{|c|}{ Total kelp gull predations } & & & 159 & 69 \\
\hline
\end{tabular}


(Table 1). Predation events generally began with a group of pelicans flying around the island, apparently surveying for areas with chicks. Those eaten ranged from small downy chicks to large, well-feathered chicks about threequarter adult size (but still unable to fly) (Supplement 1, Videos 4 \& 5, available at www.intres.com/articles/suppl/n009p125_app/). Chicks were swallowed whole while still alive (Supplement 1, Videos 1 \& 2). Hunting group sizes changed constantly (Table 1). Usually a large group would start out together, but after a while (usually after several predations) some members of the group would lag behind and eventually stop to preen or lie down. At times, a group would split to follow chicks in different locations and then join up again.

When targeting cormorants, pelicans would land near a colony and observe it to see if there were suitable chicks present. At some point, an adult cormorant would shift or a chick would emerge to beg for food, and the pelicans would exploit this opportunity to seize the chick. Pelicans sometimes repeatedly prodded a brooding adult with their beaks in an attempt to chase it off. Occasionally, they attempted to pull adults off the nest or reached under them to get at the chicks. Cormorants with chicks generally remained on the nest, while those on eggs flew off once the pelicans started probing (Supplement 1, Video 3).

\section{Effect of predation on breeding success}

Of 237 crowned cormorant nests monitored, 206 nests failed, 10 fledged chicks, while 21 remained occupied by the end of the study (Fig.2) A presumed large predation event on 19 November (Week 3) was responsible for the failure of 134 nests in $1 \mathrm{~d}$ (Fig. 2).

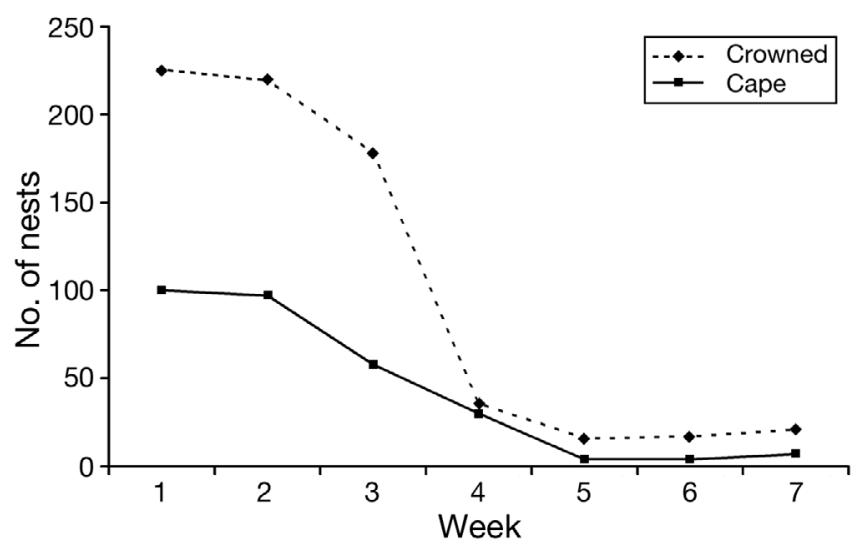

Fig. 2. Phalacrocorax coronatus and Phalacrocorax capensis. Numbers of active crowned and Cape cormorant nests monitored at Dassen Island for $7 \mathrm{wk}$ from late October to early December 2006
Although this predation event was not observed, a follow-up event was filmed the next day (Table 1). Only 18 chicks fledged, giving a crude breeding success of 0.08 fledglings per nest. At the end of the study, 122 crowned cormorant pairs (59\% of pairs that lost chicks) were starting to lay. We could not establish whether these were new breeders or failed breeders that were re-laying.

Of 107 Cape cormorant nests, none fledged chicks. At the beginning of the study there were 100 occupied nests, but only 7 remained by the end of the study (Fig. 2). No re-laying was observed.

In the first week of the study, there were 3 occupied bank cormorant nests and 17 nests being built. By the end of the study, breeding activity had ceased (Fig. 3). No bank cormorant chicks fledged from the monitored nests. Predation was not seen, but pelican disturbance was observed around their breeding area. In one instance, a pelican landed among breeding cormorants at Ichaboe Point and flushed a bank and a crowned cormorant from their nests. Rough seas washed off many of the nests that were being built and a few that were incubating in Week 3 (Fig. 3).

White-breasted cormorants bred in association with great white pelicans but were not observed being disturbed by them. Of 23 monitored nests, 11 failed, 7 fledged 10 chicks ( 0.56 fledglings per nest) and 5 were still active at the end of the study. The daily nest survival rate was $0.9875 \pm 0.0038$ (SD) and the estimated nest success (Mayfield's) was 36.9\% (95\% CI 20.5 to $66.4 \%$ ). By the end of the study, 8 new nests had been constructed at the edge of the colony. The number of active nests remained relatively stable during the study (Fig. 3).

The 144 monitored kelp gull nests contained 296 eggs and 52 chicks at the beginning of the study. Of these eggs, 136 (46\%) hatched successfully, 159 were

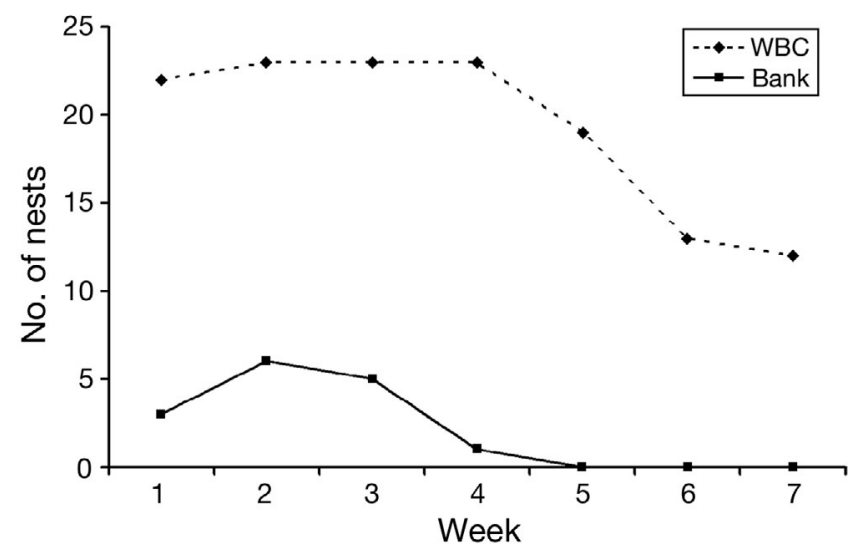

Fig. 3. Phalacrocorax neglectus and Phalacrocorax lucidus. Numbers of active bank and white-breasted cormorant nests monitored at Dassen Island for 7 wk from late October to early December 2006 


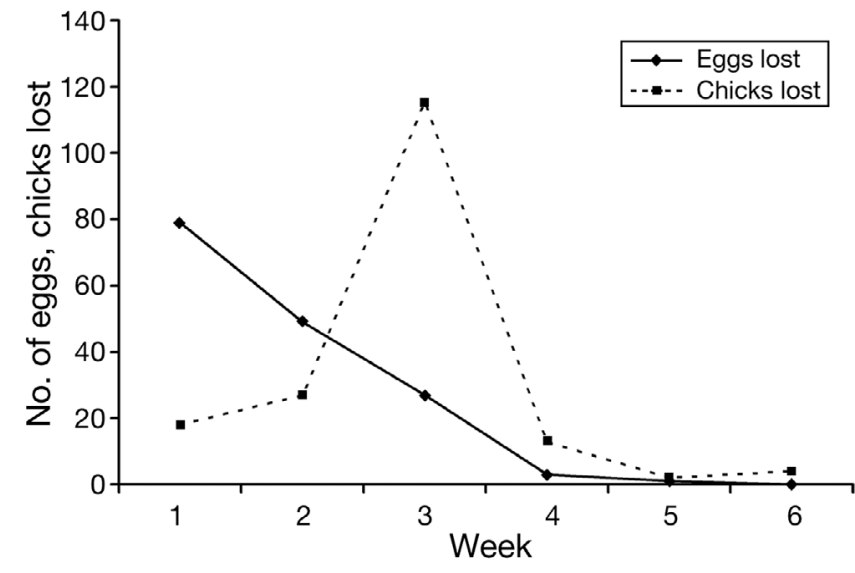

Fig. 4. Larus dominicanus vetula. Number of kelp gull eggs and chicks lost due to great white pelican predation from late October to early December 2006

lost probably due to predation by other kelp gulls and 1 egg failed to hatch. Clutch size was 1 to 3 (mean \pm SD: $2.3 \pm 0.71 ; 13.6 \%$ of nests had 1 egg, $38.4 \% 2$ eggs and $48 \% 3$ eggs). Only 9 chicks survived, giving a crude breeding success of 0.063 fledglings per nest. Predation on kelp gull chicks by pelicans peaked between 13 and 20 November (Table 1), which was reflected in the monitored nests, where the greatest number of chicks was lost between these dates (Weeks 2 and 3) (Fig. 4). Egg loss decreased almost linearly as fewer eggs became available for predation (Fig. 4).

\section{DISCUSSION}

Previous studies (Crawford et al. 1995,1997) have reported cases of pelican predation on seabird chicks, but this is the first study to quantify the impact of these predations. Pelicans were not seen to eat any eggs, although this has been reported elsewhere in southern Africa (Layard \& Sharpe 1884, Symons 1924, Berry 1976), and in North America (Mora 1989). If egg predation occurs at Dassen Island, it must be relatively infrequent.

The crowned cormorant was the most abundant cormorant breeding at Dassen Island during the study. The 237 nests observed represent some $13 \%$ of South Africa's total breeding population (du Toit et al. 2003). The crude breeding success of 0.08 fledglings per pair is far below the normal breeding success of 1.3 fledglings per pair (Williams \& Cooper 1983). The loss of almost all nests in the largest colony over $2 \mathrm{~d}$ shows how vulnerable this species is to pelican predation. Nonetheless, with the relatively large number of nests that were being constructed at the end of the study, it is possible that more chicks may have fledged later in the year. The crowned cormorant population has been stable for some years, resulting in a recommendation to downlist it to Least Concern (du Toit et al. 2003). This recommendation might be premature, given that predation at Dassen Island impacts the fourth largest crowned cormorant colony in South Africa (du Toit et al. 2003).

Cape cormorants were the second most abundant breeding cormorant, although the number of breeding pairs in 2006 was very low compared to previous years. In 2001, 9600 pairs (some $10 \%$ of South Africa's total breeding population) bred at Dassen Island (du Toit et al. 2003). Numbers of Cape cormorants breeding vary greatly between years in relation to food abundance (Barnes 2000). Although predation pressure was high on the few nests present, the impact of predation on this species can only be determined in years when large colonies breed here.

Bank cormorants experienced almost complete breeding failure at Dassen Island during the study. Numbers of breeding bank cormorants declined from 211 pairs in 1978 (Cooper 1981) to 31 pairs in 1999 (du Toit et al. 2003) and 6 pairs in 2006. Although the main reason for the decline in the breeding population at Dassen Island is thought to be food related (Barnes 2000), additional pressure from pelican predation and disturbance, as well as losses due to rough seas, will only compound the problems facing this species.

The crude breeding success of 0.56 fledglings per nest for white-breasted cormorants was lower than a previous study (1.6 fledglings per nest) (Oliver \& Kuyper 1978), but it is much higher than for all other seabirds monitored in this study. If pelicans have an impact on this species, it is much less severe than on the other cormorants breeding on Dassen Island. This is interesting, because in Dassen they nest together with the pelicans.

Kelp gulls breed in large numbers at Dassen Island, with over 5000 breeding pairs counted in 2006 (South African Marine and Coastal Management unpubl.), representing some $20 \%$ of the population of Larus dominicanus vetula. Breeding success was very low (0.063 chicks per nest) compared to other studies $(0.16$ to 1.33 chicks per nest) (Williams et al. 1984, Hockey et al. 2005). Chick survival was especially low. The losses of eggs and some small chicks could probably be attributed to cannibalism by the kelp gulls (Crawford et. al. 1997), whereas most mortality of large chicks resulted from pelican predation. The Southern African kelp gull $L$. d. vetula has not received much conservation attention, because it is usually classified as a subspecies of the nominate kelp gull. Its population currently seems to be increasing (du Toit et al. 2003), but this could be a result of previous good breeding years when predation pressure from pelicans was low or non-existent. Given that most gulls 
live for over $20 \mathrm{yr}$ (Hockey et al. 2005), it will take some time for the effect of the current sustained low breeding success at Dassen (Crawford et al. 1997) and at Schaapen Island (M. de Ponte Machado, unpubl.) to become apparent. This may lead to a decline in the total kelp gull population in South Africa since these 2 sites account for some $60 \%$ of the country's total kelp gull population (du Toit et al. 2003). With DNA studies yet to be conducted to confirm whether it is a full endemic species (Jiguet 2002), it is necessary to consider this as a species for concern.

Given the impacts of pelicans on breeding seabirds at Dassen Island and, more recently, at islands around Saldanha Bay, strategies need to be developed to mitigate pelican threat. Management options include: employing anti-predator devices to protect breeding seabirds, scaring off pelicans from selected seabird colonies, reducing the availability of offal, or even selective culling of pelicans. Artificial shelters such as fences or nest boxes for kelp gull breeding areas may act as refugia for chicks. Scaring off pelicans may also help, as they are sensitive to human disturbance (de Ponte Machado 2007). However, the impacts of disturbance on other species would have to be considered carefully. Reducing the availability of offal may, in the short-term, lead to greater predation on seabirds as the pelicans switch prey, but in the long-term, predation is likely to decrease as the pelican population decreases. If less controversial methods fail, selective culling of predatory pelicans may have to be considered. Culling specialist predator gulls, when repeated regularly, has been shown to reduce predation (Guillemette \& Brousseau 2001). It is not known whether individual pelicans specialize in seabird predation or whether the whole Dassen Island population is involved. The largest group observed during a predation event on Dassen Island was 55 pelicans, but most groups ranged from 20 to 30. There is need for further study on this issue especially with regard to identification of individual pelicans. It is also critical to monitor breeding success of prey species throughout their breeding season in all areas where predation is taking place so as to assess the population-wide impacts of pelican predation.

Acknowledgements. We thank J. Visagie and N. Pita at Dassen Island for logistical support, J.C. Smith and Portnet for access to the lighthouse, L. Upfold and Marine and Coastal Management (MCM) for sea transport; L. McGregor, J. Burnside and J. Howard for additional transport. L. Underhill, A.J. Williams and P. Whittington provided additional ideas and helpful comments. This project was funded by the Tropical Biology Association (TBA), Percy FitzPatrick Institute, University of Cape Town International Students Scholarship, Animal Demography Unit and UCT Science Faculty publishing grant. We are also grateful to the 3 reviewers for their input.

\section{LITERATURE CITED}

Barnes KN (1998) The important bird areas of the Western Cape. In: Barnes KN (ed) Important bird areas of southern Africa. BirdLife South Africa, Johannesburg, p 245

Barnes KN (ed) (2000) The Eskom red data book of birds of South Africa, Lesotho, and Swaziland. BirdLife South Africa, Johannesburg

BBC News (2006) Pelican swallows pigeon in park. Accessed from http://news.bbc.co.uk/2/hi/uk_news/england/london/6083468.stm

Berry HH (1976) Physiological and behavioural ecology of the Cape cormorant, Phalacrocorax capensis. Madoqua 9: $5-55$

BirdLife International (2004) Threatened birds of the world. CD ROM. BirdLife, Cambridge

BirdLife International (2009a) Species factsheet: Phalacrocorax neglectus. Available at: www.birdlife.org/datazone/ species

BirdLife International (2009b) Species factsheet: Phalacrocorax coronatus. Available at: www.birdlife.org/datazone/ species

Brooke RK (1984) South African red data book — birds. S Afr Natl Sci Prog Rep 97:213

Brown LH, Urban EK, Newman K (eds) (1982) The birds of Africa, Vol 1. Academic Press, London

Chu PC (1998) A phylogeny of the gulls (Aves: Larinae) inferred from osteological and integumentary characteristics. Cladistics 14:1-43

Cooper J (1981) Biology of the bank cormorant, Part 1. Distribution, population size, movements and conservation. Ostrich 52:208-215

Crawford RJM, Taylor RH (2000) White pelican. In: Barnes KN (ed) The Eskom red data book of birds of South Africa, Lesotho, and Swaziland. BirdLife South Africa, Johannesburg, p 136

Crawford RJM, Cooper J, Dyer BM (1995) Conservation of an increasing population of great white pelicans Pelecanus onocrotalus in South Africa's Western Cape. S Afr J Mar Sci 15:33-42

Crawford RJM, Nel DC, Williams AJ, Scott A (1997) Seasonal patterns of abundance of kelp gulls Larus dominicanus at breeding and non-breeding localities in southern Africa. Ostrich 68:37-41

de Ponte Machado M (2007) Is predation on seabirds a new foraging behaviour for great white pelicans? History, foraging strategies and prey defensive responses. In: Kirkman SP (ed) Final report of the BCLME (Benguela Current Large Marine Ecosystem) project on top predators as biological indicators of ecosystem change in the BCLME. Avian Demography Unit, Cape Town, p 131-142

de Ponte Machado M, Hofmeyr J (2004) Great white pelicans, Pelecanus onocrotalus: waterbirds or farm birds? Bird Numbers 13:11-12

del Hoyo J, Elliot A, Sargatal J (eds) (1992) Handbook of the birds of the world. Vol 1. Lynx Edicions, Barcelona

$\mathrm{du}$ Toit M, Boere GC, Cooper J, de Villiers MS and others (eds) (2003) Conservation assessment and management plan for southern African coastal seabirds. Avian Demography Unit and Apple Valley, Conservation Breeding Specialist Group, Cape Town

Guillemette M, Brousseau P (2001) Does culling predatory gulls enhance productivity of breeding common terns? J Appl Ecol 38:1-8

Hockey PAR, Dean WRJ, Ryan PG (eds) (2005) Roberts birds of southern Africa, 7th edn. Trustees of the John Voelcker Bird Book Fund, Cape Town 
Jiguet F (2002) Taxonomy of the kelp gull Larus dominicanus Lichenstein inferred from biometrics and wing plumage pattern, including two previously undescribed subspecies. Bull Br Ornithol Club 122:50-71

Johnson DH, Shaffer TL (1990) Estimating nest success: When Mayfield wins. Auk 107:595-600

Layard EL, Sharpe RB (1884) The birds of South Africa. Quaritch, London

Mayfield H (1961) Nesting success calculated from exposure. Wilson Bull 73:255-261

Mayfield H (1975) Suggestions for calculating nest success. Wilson Bull 87:456-466

Mora MA (1989) Predation by a brown pelican at a mixedspecies heronry. Condor 91:742-743

Oliver MD, Kuyper MA (1978) Breeding biology of the whitebreasted cormorant in Natal. Ostrich 49:25-30

Editorial responsibility: Brendan Godley,

University of Exeter, Cornwall Campus, UK
Sangster G (1999) Relationships among gulls: new approaches. Dutch Birding 21:207-218

Symons RE (1924) A visit to Dyer's Island. S Afr J Nat Hist $4: 253-259$

Votier SC, Furness RW, Bearhop S, Crane JE and others (2004) Changes in fisheries discard rates and seabird communities. Nature 427:727-730

Williams AJ, Cooper J (1983) The crowned cormorant: breeding biology, diet and offspring reduction strategy. Ostrich 54:213-219

Williams AJ, Cooper J, Hockey PAR (1984) Aspects of the breeding biology of the kelp gull at Marion Island and in South Africa. Ostrich 55:147-157

Wolfaardt A (2000) Dassen Island management plan. Western Cape Nature Conservation Board, Cape Town

Submitted: April 9, 2008; Accepted: October 5, 2009

Proofs received from author(s): January 2, 2010 